ISSN 1392-3196 / e-ISSN 2335-8947

Zemdirbyste-Agriculture, vol. 104, No. 3 (2017), p. 267-276

DOI $10.13080 /$ z-a.2017.104.034

\title{
Growth and developmental responses of crop plants under drought stress: a review
}

\author{
Shakeel Ahmad ANJUM ${ }^{1}$, Umair ASHRAF², Ali ZOHAIB ${ }^{1}$, Mohsin TANVEER ${ }^{3}$, \\ Muhammad NAEEM ${ }^{4}$, Iftikhar ALI ${ }^{1}$, Tahira TABASSUM ${ }^{1}$, Usman NAZIR ${ }^{1}$ \\ ${ }^{1}$ University of Agriculture \\ Faisalabad 38040, Pakistan \\ E-mail: alizohaib208@gmail.com \\ ${ }^{2}$ College of Agriculture, South China Agricultural University \\ Guangzhou 510642, China \\ ${ }^{3}$ School of Land and Food, University of Tasmania \\ Hobart 7001, Australia \\ ${ }^{4}$ Nigde University \\ Nigde 51240, Turkey
}

\begin{abstract}
Water deficit conditions are a bearing on plant growth and development leading to diminished crop productivity. However, improving the crop productivity is need of the time to sustain the food security under ever increasing world population. Drought episodes are increasing with varying intensity and duration. Drought stress imposes alterations in crucial plant growth and developmental processes, including germination, plant height, stem diameter, number of leaves, leaf size and area, dry matter production and partitioning, flower and fruit production, and maturity. Nonetheless, plants show some morphological changes to cope with drought stress by lowering water loss, enhanced water uptake and maintenance of tissue water status. Some plants complete their life cycle early before the onset of drought to escape water deficit conditions. Identification of effects of drought stress on morphological attributes and morphological changes in response to drought can be promising for selection and breeding of drought resistant genotypes.
\end{abstract}

Key words: drought, growth and development, morphology, phenology, plant responses.

\section{Introduction}

Food security is principally having immovable access to moderate, satisfactory and nutritious food supplies, sufficiently adequate to escape unending hunger and hindered development and improvement. The worldwide population development rates have been expected to increase and the world population will reach 8 billion by 2025 (Lomborg, 2001) and might be a little more than 9 billion by 2050 (Population Reference Bureau, 2008). In the $21^{\text {st }}$ century, worldwide farming faces two key difficulties. Firstly, an expansion in the aggregate food production for ever increasing world population along with expanding shortage of water resources (Bouman, 2007). Secondly, new water resources are gradually turning out to be erratic because of worldwide climate change, population development, and contamination and over consumption of resources (Belder et al., 2005; Bouman, 2007).

Climate change has intensified the worldwide hydrological cycle and it has been recognized that the world's mean surface temperature is increasing, subsequently increasing the normal precipitation, dissipation and overflow at worldwide scale (Huntington, 2006). The outcome of a worldwide climate change has brought about the expansion of extreme events. Among the extreme meteorological events affecting the agricultural systems, dry seasons are potentially the most gradually emerging ones (Penalba, Rivera, 2013).

Among various abiotic stresses, the drought is one of the most dynamic and worse stresses that hinder the plant growth and development, and limit the crop productivity more than any other ecological component depending on the genotype, duration and intensity, and plant developmental stage (Shao et al., 2009; Anjum et al., 2011). In fact, drought is the plant's water deficit environment that has a potential to decrease crop yield and profitability by altering the plant growth and development, and inducing deterring effects on plant physiological and biochemical processes (Anjum et al.,

Please use the following format when citing the article:

Anjum S. A., Ashraf U., Zohaib A., Tanveer M., Naeem M., Ali I., Nazir U., Tabassum T. 2017. Growth and developmental responses of crop plants under drought stress: a review. Zemdirbyste-Agriculture, 104 (3): 267-276 DOI 10.13080/z-a.2017.104.034 
2017). Plants experience drought stress either when the water supply to roots gets to be troublesome or when the transpiration rate turns out to be high. These two conditions regularly co-occur under arid and semi-arid climates (Anjum et al., 2011). The effects of drought depend fundamentally on the timing and intensity of the stress. However, the occurrence of natural drought is largely unpredictable, making it troublesome or practically difficult to recognize water limited and non-limited agricultural systems (Cooper et al., 2006). Drought stress is a standout amongst the most essential constraining factors for plant growth and development (Saranga et al., 2002; Apel, Hirt, 2004).

Drought affects the crop growth and development through a progression of complex physio-biochemical and metabolic procedures at genetic and molecular level, for example, photosynthesis, respiration, uptake of water and nutrient elements, enzymatic activities, metabolism of organic materials, and supressed or over expression of genes encoding stress proteins and transcription factors (Saba et al., 2001; Villalobos et al., 2004; Farooq et al., 2009). How drought influences plant growth and development, physiological procedures, and improvement of yield is a blazing issue of current research. However, the drought exerts its most imperative and foremost effects on plant growth and development. Furthermore, in response to drought stress plants undertake morphological changes as a first measure. A better understanding of growth and developmental responses of crop plants to drought stress is of extreme significance as the growth and developmental traits can be utilized as indicators of drought aside from physiological and biochemical traits to induce stress tolerance and improve crop productivity (Reddy et al., 2004). This article is aimed to clarify the growth and developmental responses of crop plants to drought stress.

\section{Influence of drought stress on plant growth}

The survival of plants and animals relies upon water. It is basically required by plants for photosynthesis, nutrient uptake and transportation, keeping up turgidity and in addition lowering canopy temperature (Farooq et al., 2009). Being an integral part of plant, it plays a pivotal role in the initiation of growth and subsequent maintenance of developmental processes throughout the plant's life. Cell division and cell development are vital processes for the growth and development of the plants. Plant growth is active in limited regions of cells called meristems. Almost all mitosis and cytokinesis happen in these meristematic regions prompting cell lengthening commonly known as primary growth. Secondary growth starts and causes the cell to grow (Taiz, Zeiger, 2006). Drought stress most commonly alters the cell growth and metabolism in this region (Jaleel et al., 2009).

Turgor is additionally considered as the drought sensitive physiological process that causes stunted growth and lessened cell expansion (Taiz, Zeiger, 2006). Intrusion in the stream of water from xylem to the surrounding meristem cells hinders cell expansion in higher plants (Nonami, 1998). Low turgor pressure tremendously limits the cell development, hence causing lessened plant growth and development, and yield qualities as well. Moreover, exclusion of water films from the cells disturbs the ordinary lipid bilayer structure, dislodges layer proteins and results in the loss of membrane integrity as well as enzymatic activity disturbing the cell activity and growth (Mahajan, Tuteja, 2005). It has been observed that cell enlargement or growth can be impacted generally by mild drought stress even before photosynthesis or respiration (Alves, Setter, 2004).

On the other hand, desiccation is broader loss of water that can possibly prompt complete disruption of metabolic activities, cell structure and in the end prompts the suspension of enzymes catalysing the reactions (Jaleel et al., 2009). Water stress is characterized by a decline in cell water status, turgor and aggregate water capability of plant bringing about stomatal closure, wilting, and decrease in cell growth and development. Extreme water stress might bring about cessation of photosynthesis, aggravation of metabolism, loss of turgidity and lastly cell death (Bohnert, Jensen, 1996).

The effects of drought are prominent in different plant growth and development events. It is evident that drought stress seriously diminishes germination and seedling stand (Kaya et al., 2006). Besides, impacts of drought are reflected in diminished fresh and dry matter production, delayed tillering, shorter first internode, early senescence, fruit discoloration and unexpected death. Response of plant dry/fresh biomass ratio to water deficiency is moderately lower and in this way can be utilized as a stress indicator at the plant level (Zlatev, Lidon, 2012). In the case of maize, drought during the plant reproductive stage causes apparent delay in silking, while anthesis is not postponed to such a degree. The results lead to an increase in the anthesis-to-silking interval (ASI) which is a critical reason for yield reductions under drought stress (Byrne et al., 1995). Some important studies have outlined the significant negative impacts of drought stress on growth and development of crop plants (Table 1).

The harmful impacts of drought stress on overall plant growth and development procedures are of different nature, and can impact germination, emergence, leaf, root, tiller and stem growth and development, dry matter production, floral initiation, panicle development, pollination, fertilization, seed development, seed yield, and seed quality (Jaleel et al., 2007).

\section{Germination and stand establishment}

The impacts of drought stress rely on the span, severity and phenological stage at which the drought occurs. Reduced germination and poor stand establishment are early markers of drought stress. Absence of water contributes basically to the circumstances in which the accessibility to water would in some way or another is the key to start the germination (Harris et al., 2002). Biochemical changes in the seeds start not long after imbibition of water by the seed. Water uptake and its imbibition are dependant predominantly on the soil water availability and soil water potential. Drought stress delays imbibition process and in this way brings about diminished germination rates and at last prompts decreased germination percent and seedling vigour (Mantovani, Iglesias, 2010; Liu et al., 2015). Desclaux et al. (2000) delineated that germination and seedling establishment stages are most vulnerable to drought stress. Research conducted on five pea (Pisum sativum L.) cultivars proposed that water stress causes impeded germination and diminishes early seedling development in peas (Okcu et al., 2005). Additionally, hypocotyl length, fresh and 
Table 1. Crop plants reporting drought effects under water limited conditions

\begin{tabular}{|c|c|c|}
\hline Crop & Effects of drought stress & References \\
\hline Rice & $\begin{array}{l}\text { Increase in leaf rolling, biomass and root traits severely affected, decrease in elongation } \\
\text { and expansion growth, number of tillers as well as physiological traits, } \\
\text { i.e. photosynthesis, transpiration, leaf area index and water use efficiency }\end{array}$ & Pandey, Shukla, 2015 \\
\hline Wheat & $\begin{array}{l}\text { Exposure to drought at anthesis reduces fertility by increasing pollen sterility, } \\
\text { number of tillers and kernels per ear, and ultimately reduced yield }\end{array}$ & Barnabás et al., 2008 \\
\hline Maize & $\begin{array}{l}\text { Decreased plant height, stem diameter, leaf area, number of leaves per plant, cob length, } \\
\text { and shoot fresh and dry weight per plant. Total biomass accumulation at silking, } \\
\text { grain filling and maturity reduced by } 37,34 \text { and } 21 \% \text {, respectively }\end{array}$ & Kamara e \\
\hline Sugarcane & $\begin{array}{l}\text { Reduction in leaf area index, tiller population, number of milleable canes and cane yield } \\
\text { up to } 37 \%\end{array}$ & Vasantha et al., 2005 \\
\hline Sunflower & $\begin{array}{l}\text { Dry matter partitioning and temporal biomass distribution, shoot length, root length, } \\
\text { leaf area, total chlorophyll, chlorophyll } a, b \text { and carotenoid substantially reduced }\end{array}$ & $\begin{array}{l}\text { Manivannan et al., 2007; } \\
\text { Tahir, Mehid, 2001 }\end{array}$ \\
\hline Soybean & $\begin{array}{l}\text { Decrease in nitrogen and leaf chlorophyll content; shortened seed filling period leading } \\
\text { to smaller seeds and lower yield }\end{array}$ & De Souza et al., 1997 \\
\hline Peanut & $\begin{array}{l}\text { Reduction in shoot dry weight, nodule number, nitrogen content but increase in root } \\
\text { dry weight. Severe water stress induced production of hydrogen peroxide linked with } \\
\text { lipid and protein damage }\end{array}$ & 012 \\
\hline Cotton & $\begin{array}{l}\text { Lint yield reduction generally because of reduced growth and boll production due to } \\
\text { fewer flowers and higher boll abortions }\end{array}$ & Pettigrew, 2004 \\
\hline Barley & $\begin{array}{l}\text { Reduction in number of tillers per plant, number of spikes and grains per plant, less } \\
\text { individual grain weight leading to reduction in yield, and decreased seed germination } \\
\text { and seedling vigour }\end{array}$ & $\begin{array}{l}\text { Samarah, 2005; } \\
\text { Samarah, Alqudah, } 2011\end{array}$ \\
\hline Cladode & $\begin{array}{l}\text { The water contents of Opuntia ficus-indica cladode decreased because the water } \\
\text { storage parenchyma tissues of cladodes lost a greater fraction of water as compared to } \\
\text { chlorenchyma tissues and thus resulted in a lower turgor and plant growth }\end{array}$ & Nob \\
\hline Hibiscus & $\begin{array}{l}\text { Decreased leaf turgid and dry biomass due to decrease in relative water content, } \\
\text { stomatal conductance, turgor potential, transpiration rate and water-use efficiency of } \\
\text { Hibiscus rosa-sinensis }\end{array}$ & Egilla et al., 2005 \\
\hline Clover & $\begin{array}{l}\text { Reduced leaf area and transpiration rate leading to less reduction in water use efficiency } \\
\text { and crop yield }\end{array}$ & $\begin{array}{l}\text { Lazaridou, Koutroubas, } \\
2004\end{array}$ \\
\hline Peas & $\begin{array}{l}\text { Impaired germination and reduced early seedling growth and development by } \\
\text { polyethylene induced drought stress }\end{array}$ & Okcu et al., 2005 \\
\hline Alfalfa & $\begin{array}{l}\text { Impeded germination, root length, fresh and dry biomass of shoot and root by drought } \\
\text { at early stages }\end{array}$ & Zeid, Shedeed, 2006 \\
\hline Okra & Lessened plant height due to higher leaf senescence rate and diminished cell expansion & Bhatt, Rao, 2005 \\
\hline Sugar beet & $\begin{array}{l}\text { Reduction in dry matter production, storage root/leaf ratio, and sucrose and sugars } \\
\text { accumulation in storage root }\end{array}$ & Hoffmann, 2010 \\
\hline
\end{tabular}

dry weights of root and shoot were reduced because of water deficit achieved by polyethylene glycol in alfalfa (Medicago sativa L.) (Zeid, Shedeed, 2006).

Studies propose that germination rate decreases remarkably both in tolerant and sensitive genotypes of wheat because of water stress. The rate of germination decrease is significant under water stress of $-0.4 \mathrm{MPa}$. In the case of sensitive genotypes of wheat, diminished germination has been recorded even at $-0.1 \mathrm{MPa}$ (Singh et al., 1986). Under water deficit conditions, development is additionally connected with ATP (adenosine triphosphate) levels in the cells since establishment of seedling requires energy for the anabolism in the seed. Drought tolerance mechanism in seedling includes the regulation of ATP energy levels which brings about the reduction in osmotic potential because of the accumulation of osmotic components in developing tissues. This permits the diminished seedling development under water stress conditions at the expense of ATP (Deng et al., 2002). Hsiao (1973) arranged the drought stress in light of the water potential as given in Table 2.

Shoot development tends to be faster by virtue of better soil water availability (Akram et al., 1998). Drought
Table 2. Drought stress levels as a function of water potential

\begin{tabular}{cccc}
\hline $\begin{array}{c}\text { Serial } \\
\text { No. }\end{array}$ & $\begin{array}{c}\text { Category of } \\
\text { stress }\end{array}$ & $\begin{array}{c}\text { Soil water } \\
\text { potential }\end{array}$ & $\begin{array}{c}\text { Reduction in leaf } \\
\text { relative water } \\
\text { content } \%\end{array}$ \\
\hline 1. & Mild stress & -0.1 & $8-10$ \\
2. & Moderate stress & $-1.2--1.5$ & $>10-20$ \\
3. & Severe stress & $<-1.5$ & $>20$ \\
\hline
\end{tabular}

stress hinders the prolongation of plumule and decreases seedling vigour, which causes poor stand establishment because of shorter coleoptiles. In this way, utilization of genotypes with longer coleoptile would be an appropriate way to accomplish better stand establishment (Richards et al., 2002). During desiccation, seed viability and vigour are lost, which is particularly related to numerous biochemical changes such as reactive oxygen species (ROS) causing damage and changes in RNA, DNA and protein structures, membrane ruptures, reduction in the respiratory activity and thus reduction in ATP production (Priestley, 1986). Similar might be the reason of decreased germination rate under water stress. 


\section{Morphological attributes}

Plant height. It is a noteworthy agronomic parameter that reflects the vegetative growth behaviour of crop plants in response to the given inputs and stressed conditions (Anjum et al., 2016 a; Wang et al., 2016). In specific crops like wheat, it is associated with limited seedling development, lodging and weed control (Donald, Hamblin, 1976). It is known that drought stress is an important limiting factor that suppresses the numerous growth related traits in crop plants. The suppression in plant height is primarily ascribed to lessening in the cell expansion and elongation (Manivannan et al., 2007; Jaleel et al., 2009). Jamali and Ali (2008) reported that plant tallness influences photosynthesis which could bring about the changes in grain yield. Several studies on plants demonstrated substantial reduction in plant height because of drought stress. In soybean, stem length was slightly decreased under drought stress yet it was not much greater when compared with well-watered conditions (Specht et al., 2001). In okra (Abelmoschus esculentus (L.) Moench), plant height was lessened because of more leaf senescence and diminished cell broadening taking place after stress (Bhatt, Rao, 2005). A study was conducted to consider the impact of water stress on growth and yield of maize cultivar YHS 202. The study consisted of six treatments viz., control (six irrigations), and five, four, three, two and one irrigation. The results revealed the plant height, stem diameter; days to flowering and leaf area were altogether lessened because of water stress. Plant height was decreased to 36 and $11 \mathrm{~cm}$ in middle of mild and extreme stress, respectively (Khan et al., 2001).

Stem diameter. In some plants that have stem instead of shoots, the stem diameter is shrivelled because of changes in turgidity of cells in plants encountering drought stress (Simonneau et al., 1993). Soil water potential and leaf water potential contributes basically to change in stem diameter, while the former is all around associated with changes under delayed drought stress (Katerji et al., 1994). Yatapanage and So (2001) recorded stem diameter and predicted leaf water potential in (Sorghum bicolor (L.) Moench) and indicated promising results. Khan et al. (2001) reported that maximum stem diameter and leaf area was recorded in well-watered conditions, which gradually diminished with increasing water stress. Stem diameter and leaf area was observed to be least in plots where only a single irrigation was applied. In another study, Huang et al. (2013) noticed that stem diameter, leaf thickness and shoot fresh weight of ramie diminished up to 7, 3 and $5 \%$ by mild drought, while, substantial reduction was caused by moderate (13.6\% and $11 \%)$ and severe stress (17.9\% and 17\%), respectively.

Number of leaves per plant. The number of leaves per plant is influenced by water stress; diminished longevity and narrowing of individual leaf size are described by reduction in soil water potential (Anjum et al., 2011). Factors responsible for leaf expansion like, maintenance of leaf turgor, accumulation of assimilates and temperature were genuinely modified because of drought stress in Arachis hypogeae (L.) (Reddy et al., 2003). However, Abdelmula and Sabiel (2007) concluded that vegetative attributes (i.e. number of leaves per plant) are not influenced essentially by drought. They argued that this character is exceptionally impacted and controlled by genetic factors as opposed to the environmental factors. In any case, shedding of leaves because of drought stress lowers the water budget at the expense of yield loss (Schuppler et al., 1998).

Leaf size. The first and foremost effect of any abiotic stress is decreased leaf size (Anjum et al., 2016 b). Leaf traits like emergence, elongation and expansion are thought to be important characteristics accounted for improved photosynthesis. Higher photosynthetic rates are absolutely associated with an enhanced leaf expansion rate (He et al., 2009). Henson (1985) reported leaf size as a basis for selection of rice cultivars keeping in mind the end goal to conserve water. Varieties have been recorded in different rice lines for leaf area (result of leaf length and width). However, leaf pubescence is thought to be xeromorphic quality that shields plant from unreasonable heat shock under water stress. Leaf transpiration and in this way the temperature are decreased in hairy leaves. This attribute additionally upgrades light reflectance and increases the boundary layer imperviousness to water vapour under high radiation and water stress (Sandquist, Ehleringer, 2003). Drought stress prompts the creation of trichomes on both sides of leaves yet it does not influence essentially boundary layer imperviousness to water vapours. Water stress causes decreased cell development and diminished cell division which in long run influences the leaf size by lessening mature cell size. In young leaves, fewer cells per leaf are recorded due to the hindrance in cell division. Both of these processes, i.e. decreased cell division and elongation, decrease the leaf size. The recovery of both cell expansion and cell division is dependent on phases of leaf development. It has been found that stress occurring at early phase can be recovered but this recovery does not take place if stress occurs at the later stages and in the long run prevents the leaves to grow to full size (Alves, Setter, 2004).

Leaf area. The growth and development of leaf is more sensitive to drought than root, because plant vigour and its photosynthetic potential are the traits that can be enhanced by improving leaf area. Moreover, it also improves the water use efficiency of the crop. Leaf area is determined by stem morphology, phenology, leaf emergence rates and the potential leaf size. Any effect of drought on these factors would certainly alter leaf area. Plasticity in leaf area is an important way of maintaining control over water-use under drought stress. Elements, for example, diminished cell expansion, decrease in cell division, mortality of apical parts of leaf and leaf rolling lessens the leaf area significantly. All these processes persist in drought-stressed crop and are viewed as an essential basis in gathering crop yield through inhibition of net photosynthesis (Rucker et al., 1995; Reddy et al., 2003; 2004). In Arachis hypogeae, drought influenced the leaf turgor and supply of assimilates disturbing the leaf expansion (Reddy et al., 2004). In another study on two sympatric Populus species, a great decline was seen in the total leaf area, number of leaves and leaf biomass under drought stress (Yin et al., 2005).

Net photosynthetic rate is influenced radically by water stress because of reduction in leaf growth and area. Decrease in the leaf area expansion is emphatically associated with decrease in transpiration surface and subsequently is among the most basic development mechanism under drought stress (Alves, Setter, 2004). This sensitivity is expressed in terms of fewer and smaller cells produced by leaf meristems (Randall, Sinclair, 1988; Tardieu et al., 2000). As discussed earlier, leaf susceptibility to drought is dependent upon developmental stage, yet the pronounced effects on leaf area are categorized as mild and severe (Alves, Setter, 2004). Mild drought on leaves causes decrease in leaf 
number, leaf expansion rate and finally size of the leaf; while, severe drought stress causes diminished elongation of leaf and stops leaf development. In the long run, severe stress stops the production of new leaves influencing the total leaf size. Leaf senescence could be accelerated due to continued drought stress and elevate the rate of deceased leaf tissues bringing about leaf abscission (especially matured and old leaves) (De Souza et al., 1997).

Leaf rolling because of drought pushes extremely reduced light interception surface through decreased leaf area and prompts reduction in stomatal conductance (Earl, Davis, 2003; Saglam et al., 2014). Pre-flowering reduction in leaf area and decrease in intercepted light radiation are because of changes in leaf angle and decreased leaf expansion while post-flowering reduction is credited to progressive senescence. In this way plant's response to drought stress is different during pre and post flowering stages. Plants have evolved different mechanisms to withstand drought stress; diminishing leaf senescence, especially at post flowering stage (i.e. during grain-filling stages) is an important adaptation. Interestingly, the decline in leaf area can serve as drought avoidance mechanism that can restrict further water loss (Farooq et al., 2009). Comparative reports from pot and field trials demonstrated that drought decreases the rate of leaf appearance and decreases the total assimilatory surface of leaves by more than half (Kazakov et al., 1988).

Stomatal sensitivity in several plant species diminishes at post flowering stages in response to leaf water deficiency, so a more prominent water deficit is required to close the stomata. Under drought stress, if spikelets or grains are expelled from wheat ear, flag leaf demonstrates diminished stomatal conductance and holds water status in flag leaf (Blum, 1988).

Leaf area index (LAI). It is the ratio of leaf area to ground area and is considered as a good indicator for crop growth and soil conditions for enhancing crop productivity. It is the basic physiological tool that shows the size of crop assimilates under field conditions. A noticeable decrease in LAI has been recorded in crop plants under drought stress. For example, Hussain et al. (2008) observed persistent decrease in LAI at maturing and flowering phases of sunflower (Helianthus annuus L.) subjected to drought stress.

Dalirie et al. (2010) considered differences in patterns of leaf area index in wheat genotypes as influenced by terminal drought stress. In his study, LAI values achieved greatest level at 240-250 days after planting and after that indicated decreasing pattern with increasing duration of terminal drought stress, until harvest. This decline in LAI is credited to accelerated leaf senescence, competition for light and other resources, especially under water deficit conditions. Capture of total solar radiation by the plant can be enhanced by increasing LAI in wheat genotypes and it influences dry matter production. Thus, dry matter production diminishes with a decrease in LAI. Winter and Ohlrogge (1993) are of the view that grain yield and total dry matter production is significantly associated with leaf angle and LAI. In any case, Weber et al. (1996) reported that LAI and total dry matter were poor indicators of grain yield.

Generally a novel idea of reduced sink development was appropriate to explain the source limitation driven by LAI (Supit, der Groot, 2003). Limitation of source, for example, associated with decrease in leaf area and diminished photosynthetic efficiency frequently causes decreased translocation of assimilates to the sink. For instance, in maize water stress provoked changes in translocation of assimilates by antagonistically influencing the compounds included in photosynthesis. Water loss in different stress tolerant cultivars was decreased by shifting stomatal conductance (Pelleschi et al., 1997).

Accurate simulation of LAI is a vital approach for precise simulation of biomass and transpiration and vice versa. Biomass accumulation is influenced by partitioning to the leaves to form new leaf area. A typical LAI model runs with a slow increase during early season followed by a rapid increase until a maximum value of LAI is reached. Afterwards, it declines as plants reach physiological maturity. Boote et al. (1998) reported a few methodologies for simulating LAI in soybean (Glycine max L. Merr) crop. While, Robertson et al. (2002) gave ordinary crop models relevant to soybean crop. Teruel et al. (1997) reported LAI modelling in sugarcane (Saccharum officinarum L.) to different water stress conditions. The study exhibits relationship in the middle of evapotranspiration and LAI to fluctuating levels of soil water deficit. In the case of high soil water deficit, leaf area index decreases but this decline in LAI is less than evapotranspiration rate, whereas, under low soil water deficit, rate of evapotranspiration is less affected compared to LAI.

Plant biomass accumulation. Suppression in dry biomass production in response to abiotic stresses has been reported (Anjum et al., $2016 \mathrm{c}$; Niu et al., 2016). Under drought stress, the productivity of a plant relies on some essential processes such as temporal biomass distribution and dry matter partitioning. Biomass decreases in response to drought have been noticed in numerous crops, for example, sunflower (Tahir, Mehid, 2001), green gram (Webber et al., 2006), soybean (Specht et al., 2001), parsley (Petropoulos et al., 2008) and bitter orange seedlings (Wu et al., 2008) under water stress. In sugar beet, the loss in shoot dry weight was more than root dry weight when exposed to severe water stress. However, the tolerance to stress may be different in different genotypes (Mohammadian et al., 2005). Lafitte et al. (2007) noticed moderate water stress tolerance in terms of shoot dry weight in rice.

More fresh and dry weight of plant under restricted supply of water is desirable character. Enhanced seedling stand is identified with dry weight of seedling which changes from species to species. A typical unfavourable impact of water stress on crop plants is the reduction in fresh and dry biomass production (Farooq et al., 2009). In sunflower, decrease in plant biomass and yield per plant was recorded because of water stress (Tahir et al., 2002).

Root to shoot ratio is increased under drought stress and it is related to increased concentration of abscisic acid (ABA) in roots and shoots. Drought stress exalts the translocation of dry matter to roots to enhance water uptake (Leport et al., 2006). De Souza and Da Silv (1987) examined the photo-assimilates distribution and partitioning in perennial and annual cotton under drought stress. They found that root-to-shoot dry matter ratio was higher in perennial cotton, which was mainly due to the accumulation of starch and dry matter in roots under drought stress. Hence, perennial cotton showed drought resistance through assimilate partitioning which favours starch accumulation and growth of the root system. Torres et al. (2006) suggest that thick and profound root structure is useful in extraction of water from significant soil depths. Therefore, plants utilize it as avoidance mechanism under water stress. Studies further suggest that extraction of water during growing season is strongly related to distribution and structure (i.e. quality) 
of roots not its quantity (Subbarao et al., 1995). In this way, selection of genotypes having deep and extensive root system has been a benchmark to obtain higher crop productivity.

Netassimilation rate (NAR). Water stress prompts decrease in net photosynthesis and changes chloroplast capacities. The decline in NAR under drought firmly shows the stomatal closure for decrease in growth during increased levels of stress. A study revealed that NAR was reduced in the drought stressed okra cultivars. Among the cultivars, 'JK Haritha' demonstrated the highest NAR (79\%) under water deficit conditions; while, lowest NAR $(61 \%)$ was recorded in SPHB 7 contrasted with different cultivars, as compared to control (Sankar et al., 2008). The NAR was moderately lower in dry spell depending on the severity of dry spell in group bean (Vyas et al., 2001). The decrease in NAR strongly indicates stomatal closure factor for reduction during increased levels of water stress (Siemens, Zwiazek, 2003).

\section{Effect of drought on plant developmental processes}

Plant development is restricted in the presence of drought stress. The duration of developmental processes like spike development is reduced after stress which extremely influences kernel size, weight and number. Frederick and Camberato (1995) reported that water stress before anthesis decreased leaf area of winter wheat and was associated with decrease in the number of kernels per spike. Nevertheless, if drought stress occurs at later phases of panicle and/or flowering, it can increase time from seed set to full seed development. In the case of cereals, expanded periods of reproductive development during stress may be an approach to increase the quantity of productive tillers and kernels for giving significant supply of assimilates during the grain filling (Prasad et al., 2008).

Grain filling duration is the time from seed set to the physiological maturity. It is well known that seed yield is reduced if plants are encountered by drought stress during the seed development. The evident impacts are shortening of seed filling period which lessens the final seed size (Pervez et al., 2009). On the off chance, if water stress occurred right on time during seed filling period then it might bring about decrease in number of seeds. Amazingly, short seed filling period is a versatile characteristic in plant species exposed to water stress (Fougereux et al., 1997).

Among various plant developmental processes that are affected by drought the most important processes are the plant source sink relationship, leaf senescence and plant phenological development that ultimately affects the various growth processes and plant productivity.

Leaf senescence and source-sink relationship. During grain filling, delayed leaf senescence is the consequence of elements happening at early crop growth. It is mostly because of improved balance between the demand and supply of water, and additionally, the productivity with which the crop changes over water to biomass and grain yield (Jordan et al., 2012). On the supply side, crop water use during grain filling so as to fill can be improved by water availability at anthesis and increasing water availability during grain filling (Van Oosterom et al., 2011). On the demand side, crop water use can be diminished by diminishing leaf area or transpiration per unit leaf area (Borrell et al., 2014).

Drought stress hastens leaf senescence and death rate of leaves and is considered as an adaptive process of survival, i.e. assuming the concept of "kick the bucket and let live" (De Souza et al., 1997; Munné-Bosch, Alegre, 2004). Old leaves cause closure of stomata, decrease water loss through transpiration, consequently ready to hold the restricted amounts of water by the younger leaves. As the drought advances, leaf senescence happens from older to younger leaves, plant in these conditions get by remobilizing its supplements from source (senescing leaves) to the sink (younger leaves). Drought driven leaf senescence enhances the early remobilization of resources from vegetative growth to reproductive growth, subsequently prompt the accelerated completion of vegetation cycle (Munné-Bosch, Alegre, 2004).

Drought induces modifications in several endogenous plant hormones, as the leaf continues towards maturing. A decrease in the levels of cytokinins and increase in the levels of ABA were observed in wheat (Ali et al., 1999). Production of ROS increases, which prompts the antioxidant defence system, after exposure to drought stress. In drought stressed wheat and rice, studies have indicated that carbon remobilization from senescing leaves to grains increases due to enhanced ABA concentrations. Roitsch and Ehneß (2000) demonstrated that cytokinins play a remarkable part in the regulation of source sink translocation. Under stressed conditions cytokinins progress cell division and elongation so that younger leaves could carry on as sink. Diminished cytokinins production by the roots is associated with drought stress, which can possibly hasten senescence in the older leaves by hindering its generation (Xu et al., 2016). Acid invertase is assumed to be an imperative part in the carbohydrate metabolism, which is definitely recognized with the remobilization of storage reserves from leaves or stems (Zinselmeier et al., 2000), its action is likewise impeded by drought stress (Zinselmeier et al., 1995). Remobilization of nutrients to the younger leaves is a survival technique, which keeps them alive and permit them to get by showing elevated levels of photoand anti-oxidative protection throughout stress period, with the goal that it can continue its development as the conditions get to be ideal (Munné-Bosch, Alegre, 2004).

Phenological development. Drought stress affects the plant phenological stages. Both the duration and intensity of stress not only affect the stage of development but also the transition of one developmental stage to another. Flowering time constitutes marked developmental changes in plants which initiates after termination of vegetative phase in the case of crops showing determinate growth habit. Conversion of vegetative meristems into floral parts is the beginning of reproductive phase. Both occur simultaneously in indeterminate crops. Drought alters initiation as well as the duration of these vital developmental processes. Moderate drought diminishes the length of time from flowering to anthesis (i.e. drought escape); however, it might be increased under severe water stress (Prasad et al., 2008).

In the case of rice, drought stress inhibits the development of panicle and plant transition from vegetative to reproductive phase is limited, with an outcome it will stay in vegetative stage until conditions get to be better. Craufurd and Peacock (1993) depicted that initiation of panicle is confined for 2 to 25 days, while, in sorghum the flowering was delayed from 1 to 59 days under severe drought stress. Blossoming and panicle exertion is restrained because of serious dry season push (Cruz, O'Toole, 1984) and is attributed to reduction in pollen or ovule function, elevated pollen sterility, both led to a deduction in fertilization (Rang et al., 2011).

Drought stress disturbs source sink relationship by constraining the rate of photosynthesis; deferred 
ear development and silk emergence are attributed to diminished flux of assimilates to the developing ears (Schussler, Westgate, 1995). Drought stress prolongs anthesis to silking interval termed as anthesis-to-silking interval (ASI), eventually influencing pollen viability and its release, fertilization, silk receptivity, silk emergence and kernel set (Saini, Westgate, 2000). In addition, Kamara et al. (2003) revealed that aggregate biomass production at silking, grain filling period and development were diminished by 37,34 and $21 \%$ individually, because of water stress induced at different developmental stages in maize. Cell development and division, turgidity, synthesis of new protoplasm are physiological traits affected by water stress at reproductive stage (Alves, Setter, 2004).

\section{Conclusion}

Drought stress severely hampers the plant growth and development starting from the germination until maturity. Decrease in growth occurs due to impaired cell division and elongation because of limited turgor. Germination and stand establishment are reduced due to lowered water potential and imbibition. Furthermore, different indices of growth such as plant height, number of leaves, leaf size and area, leaf area index (LAI) are decreased, which leads to a decline of photosynthesis and dry matter accumulation under drought; moreover, net assimilation rate (NAR) is also declined which indicates the stomatal closure due to drought stress. Plants also undergo developmental and phenological changes when exposed to drought stress such as delayed start of reproductive stage in determinate plants, reduced grain filling period, reduced fertilization and number of grains, and leaf senescence initiates earlier because of limited water potential. Determination and identification of effects of drought on morphological attributes and morphological changes occurring in response to drought can be helpful for selection and breeding of drought resistant genotypes.

Received 18122016 Accepted 04052017

\section{References}

1. Abdelmula A. A., Sabiel S. A. I. 2007. Genotypic and differential responses of growth and yield of some maize (Zea mays L.) genotypes to drought stress. Proceedings of the tropial conference on international agricultural research for development Tropentag 2007. University of KasselWitzenhausen and University of Göttingen, Germany, 6 p.

2. Akram H. M., Ahamd N., Ali A. Yar A. 1998. Effect of stress on germination and seedling growth of wheat cultivar. Journal of Agricultural Research, 36 (3): 216-222.

3. Ali M., Jensen C. R., Mogensen V. O., Andersen M. N., Henson I. E. 1999. Root signalling and osmotic adjustment during intermittent soil drying sustain grain yield of field grown wheat. Field Crons Research. 62 (1): 35-52. https://doi.org/10.1016/S0378-4290(99)00003-9

4. Alves A. A. C., Setter T. L. 2004. Response of cassava leaf area expansion to water deficit: cell proliferation, cell expansion and delaved develonment. Annals of Botany, 94 (4): 605-613. https://doi.org/10.1093/aob/mch179

5. Anjum S. A., Xie X. Y., Wang L. C., Saleem M. F., Man C, Lei W. 2011. Morphological, physiological and biochemical responses of plants to drought stress. African Journal of Agricultural Research, 6 (9): 2026-2032.

6. Anjum S. A., Ran W., Jian-hang N., Zohaib A., Jin-huan L., Mei-ru L., Ji-xuan S., Jun L., San-gen W., Xue-feng Z. 2016 (a). Exogenous application of ALA regulates growth and physiological characters of Leymus chinensis (Trin.) Tzvel. under low temperature stress. Journal of Animal and Plant Sciences, 26 (5): 1354-1360.

7. Anjum S. A., Jian-hang N., Ran W., Jin-huan L., Mei-ru L., Ji-xuan S., Jun L., Zohaib A., San-gen W., Xue-feng Z. 2016 (b). Regulation mechanism of exogenous 5-aminolevulinic acid on growth and physiological characters of Leymus chinensis (Trin.) under high temperature stress. The Philippine Agricultural Scientist, 99 (3): 253-259.

8. Anjum S. A., Li J. H., Lv J., Zong X. F., Wang L., Yang A. J., Yan R., Zohaib A., Song J. X., Wang S. G. 2016 (c). Regulation mechanism of exogenous ALA on growth and physiology of Leymus chinensis (Trin.) under salt stress. Chilean Journal of Agricultural Research. 76 (3): 314-320. https://doi.org/10.4067/S0718-58392016000300008

9. Anjum S. A., Ashraf U., Tanveer M., Khan I., Hussain S., Zohaib A., Abbas F., Saleem M. F., Wang L. 2017. Drought tolerance in three maize cultivars is related to differential osmolyte accumulation, antioxidant defense system, and oxidative damage. Frontiers in Plant Science, 8: 1-12.

10. Apel K., Hirt H. 2004. Reactive oxygen species: metabolism, oxidative stress, and signal transduction. Annual Review of Plant Biology, 55: 373-399. https://doi.org/10.1146/annurev.arplant.55.031903.141701

11. Barnabás B., Jäger K., Fehér A. 2008. The effect of drought and heat stress on reproductive processes in cereals. Plant, Cell and Environment, 31 (1): 11-38.

12. Belder P., Spiertz J. H. J. L, Bouman B. A. M., Lu G., Tuong T. P. 2005. Nitrogen economy and water productivity of lowland rice under water saving irrigation. Field Crops Research. 93 (2): 169-185. https://doi.org/10.1016/j.fcr.2004.09.022

13. Bhatt R. M., Rao N. K. S. 2005. Influence of pod load response of okra to water stress. Indian Journal of Plant Physiology, 10 (1): 54-59.

14. Blum A. 1988. Plant breeding for stress environments, $223 \mathrm{p}$.

15. Bohnert H. J., Jensen R. G. 1996. Strategies for engineering water stress tolerance in plants. Trends in Biotechnology, 14 (3): 89-97. https://doi.org/10.1016/0167-7799(96)80929-2

16. Boote K. J., Jones J. W., Hoogenboom G. 1998. Simulation of crop growth: CROPGRO model. Peart R. M., Curry R. B. (eds.). Agricultural systems modeling and simulation. New York, USA.

17. Borrell A. K., Mullet J. E., George-Jaeggli B., van Oosterom E. J., Hammer G. L., Klein P. E., Jordan D. R. 2014. Drought adaptation of stay-green sorghum is associated with canopy development, leaf anatomy, root growth, and water untake. Journal of Exneriment Botany, 65: 6251-6263. https://doi.org/10.1093/jxb/eru232

18. Bouman B. A. M. 2007. A conceptual framework for the improvement of crop water productivity at different spatial scales. Agricultural Systems, 93 (1): 43-60. https://doi.org/10.1016/j.agsy.2006.04.004

19. Byrne P. F., Bolanos J., Edmeades C. O., Eaton D. L. 1995. Gains from selection under drought versus multi location testing in related tronical maize nonulations. Cron Science 35 (1): 63-69. https://doi.org/10.2135/cropsci1995.0011183X003500010011x

20. Cooper M., van Eeuwijk F., Chapman S. C., Podlich D. W., Löffler C. 2006. Genotype-by-environment interactions under water-limited conditions. Ribaut J.-M. (ed.). Drought adaptation in cereals. New York, USA, p. 51-96.

21. Craufurd P. Q., Peacock J. M. 1993. Effect of heat and drought stress on sorghum (Sorghum bicolor). II. Grain vield. Experimental Agriculture. 29 (1): 77-86. https://doi.org/10.1017/S0014479700020421

22. Cruz R. T., O'Toole J. C. 1984. Dry land rice response to an irrigation gradient at flowering stage. Agronomy Journal, $76(2): 178-183$. https://doi.org/10.2134/agronj1984.00021962007600020003x

23. Dalirie M. S., Sharifi R. S., Farzaneh S. 2010. Evaluation of yield, dry matter accumulation and leaf area index in wheat genotypes as affected by terminal drought stress. Notulae Botanicae Horti Agrobotanici Cluj-Napoca, 38 (1): 182-186.

24. De Souza J. G., Da Silv J. V. 1987. Partitioning of carbohydrates in annual and perennial cotton (Gossypium hirsutum L.). Journal of Experimental Botany, 38 (7): 1211-1218. https://doi.org/10.1093/jxb/38.7.1211

25. De Souza P. I., Egli D. B., Bruening W. P. 1997. Water stress during seed filling and leaf senescence in soybean. Agronomy Journal. 89 (5): 807-812. https://doi.org/10.2134/agronj1997.00021962008900050015x

26. Deng X., Shan I., Shinobu I. 2002. High efficient use of limited supplement water by dryland spring wheat. Transactions of the ASAE, 18 (5): 84-91. 
27. Desclaux D., Huynh T. T., Roumet P. 2000. Identification of soybean plant characteristics that indicate the timing of dronght stress. Cron Science, 40 (3): 716-722. https://doi.org/10.2135/cropsci2000.403716x

28. Donald C. M., Hamblin J. 1976. The biological yield and harvest index of cereals as agronomic and plant breeding criteria. Advances in Agronomv. 28: 361-405. https://doi.org/10.1016/S0065-2113(08)60559-3

29. Earl H. J., Davis R. F. 2003. Etfect of drought stress on leaf and whole canopy radiation use efficiency and yield of maize. Agronomy Journal, 95 (3): 688-696. https://doi.org/10.2134/agronj2003.0688

30. Egilla J. N., Davies Jr. F. T., Boutton T. W. 2005. Drought stress influences leaf water content, photosynthesis, and water-use efficiency of Hibiscus rosa-sinensis at three notassium concentrations. Photosvnthetica. 43 (1): 135-140. https://doi.org/10.1007/s11099-00்5-5140-2

31. Farooq M., Wahid A., Kobayashi N., Fujita D., Basra S. M. A. 2009. Plant drought stress: effects, mechanisms and management. Agronomy for Sustainable Development, 29: 185-212. https://doi.org/10.1051/agro:2008021

32. Fougereux J. A., Dore T., Ladonne F., Fleury A. 1997. Water stress during reproductive stages affects seed quality and vield of nea. Cron Science. 37 (4): 1247-1252. https://oi.org/10.2135/cropsci1997.0011183X003700040036x

33. Frederick J. R., Camberato J. J. 1995. Water and nitrogen effects on winter wheat in the southeastern Coastal Plain. I. Grain yield and kernel traits. Agronomy Journal, 87 (3): 521-526. https://doi.org/10.2134/agronj1995.00021962008700030021x

34. Furlan A., Llanes A., Luna V., Castro S. 2012. Physiological and biochemical responses to drought stress and subsequent rehydration in the symbiotic association peanutBradvrhizobium sp. ISRN Agronomy, 2012: 1-8. https://doi.org/10.5402/2012/318083

35. Harris D., Tripathi R. S., Joshi A. 2002. On-farm seed priming to improve crop establishment and yield in dry direct-seeded rice. Pandey S. et al. (eds.). Direct seeding: research strategies and opportunities. International Research Institute, Manila, Philippines.

36. He L., Gao Z., Li R. 2009. Pretreatment of seed with $\mathrm{H}_{2} \mathrm{O}_{2}$ enhances drought tolerance of wheat (Triticum aestivum L.) seedlings. African Journal of Biotechnology, 8 (22): 6151-6157. https://doi.org/10.5897/AJB09.490

37. Henson I. E. 1985. Modification of leaf size in rice (Oryza sativa L.) and its effects on water stress-induced abscisic acid accumulation. Annals of Botany. 56 (4): 481-487. https://doi.org/10.1093/oxfordjournals.aob.a087033

38. Hottmann C. M. 2010. Sucrose accumulation in sugar beet under drought stress. Journal of Agronomy and Crop Science. 196 (4): 243-252 https://doi.org/10.1111/j.1439-037X.2009.00415.x

39. Hsiao T. C. 1973. Plant responses to water stress. Annual Review of Plant Physiology. 24 (1): 519-570. https://doi.org/10.1146/annurev.pp.24.060173.002511

40. Huang C., Zhao S., Wang L., Anjum S. A., Chen M., Zhou H., Zou C. 2013. Alteration in chlorophyll fluorescence, lipid peroxidation and antioxidant enzymes activities in hybrid ramie (Boehmeria nivea L.) under drought stress. Australian Journal of Crop Science, 7 (5): 594-601.

41. Huntington T. G. 2006. Evidence for intensification of the global water cycle: review and synthesis. Journal of Hydrology, 319 (1): 83-95. https://doi.org/10.1016/j.jhydrol.2005.07.003

42. Hussain M., Malik M. A., Farooq M., Ashraf M. Y. Cheema M. A. 2008. Improving drought tolerance by exoge-nous application of glycinebetaine and salicylic acid in sunflower. Journal of Agronomy and Crop Science, 194 (3): 193-199. https://doi.org/10.1111/j.1439-037X.2008.00305.x

43. Jaleel C. A., Manivannan P., Sankar B., Kishorekumar A., Gopi R., Somasundaram R., Panneerselvam R. 2007. Water deficit stress mitigation by calcium chloride in Catharanthus roseus: effects on oxidative stress, proline metabolism and indole alkaloid accumulation. Colloids and Surfaces B: Biointerfaces, 60 (1): 110-116.

https://doi.org/10.1016/j.colsurfb.2007.06.006

44. Jaleel C. A., Manivannan P., Wahid A., Farooq M., Somasundaram R., Panneerselvam R. 2009. Drought stress in plants: a review on morphological characteristics and pigments composition. International Journal of Agriculture and Biology, 11 (1): 100-105.
45. Jamali K. D., Ali S. A. 2008. Yield and yield components with relation to plant height in semi-dwarf wheat. Pakistan Journal of Botany, 40 (4): 1805-1808.

46. Jordan D. R., Hunt C. H., Cruickshank A. W., Borrel A. K., Henzell R. G. 2012. The relationship between the stay-green trait and grain yield in elite sorghum hybrids grown in a range of environments. Cron Science, 52 (3): 1153-1161. https://doi.org/10.2135/cropsci2011.06.0326

47. Kamara A. Y., Menkir A., Badu-Apraku B., Ibikunle O. 2003. The influence of drought stress on growth, yield and yield components of selected maize genotypes. Journal of Agricultural Science, 141 (1): 43-50. https://doi.org/10.1017/S0021859603003423

48. Katerji N., Tardieu F., Bethenod O., Quetin P. 1994. Behavior of maize stem diameter during drying cycles: comparison of two methods for detecting water stress. Crop Science, 34 (1): 165-169. https://doi.org/10.2135/cropsci1994.0011183X003400010029x 49. Kaya M. D., Ukçub G., Ataka M., Çı1kılıc Y., Kolsarıcıa Ü. 2006. Seed treatments to overcome salt and drought stress during germination in sunflower (Helianthus annuus L.). Euronean Journal of Agronomy, 24 (4): 291-295. https://doi.org/10.1016/j.eja.2005.08.001

50. Kazakov E. A., Kazakova S. M., Gulyaev B. I. 1988. The effect of soil humidity on formation and necrosis of sugarbeet leaf apparatus. Fiziologiya i Biokhimiya Kulturnykh Rastenii, 20 (5): 431-438.

51. Khan M. B., Hussain N., Iqbal M. 2001. Effect of water stress on growth and yield components of maize variety YHS 202. Journal of Research Science, 12: 15-18.

52. Lafitte H. R., Yongsheng G., Yan S., Li Z. K. 2007. Whole plant responses, key processes, and adaptation to drought stress: the case of rice. Journal of Exnerimental Botany, 58 (2): 169-175. https://doi.org/10.1093/jxb/erl101

53. Lazaridou M., Koutroubas S. D. 2004. Drought ettect on water use efficiency of berseem clover at various growth stages. Proceedings of the $4^{\text {th }}$ international crop science congress New Directions for a Diverse Planet. Brisbane, Australia.

54. Leport L., Turner N. C., French R. J., Barr M. D., Duda R., Davies S. L. 2006. Physiological responses of chickpea genotypes to terminal drought in a Mediterranean-type environment. European Journal of Agronomy, 11 (3): 279-291.

55. Liu M., Li M., Liu K., Sui N. 2015. Effects of drought stress on seed germination and seedling growth of different maize varieties. Journal of Agricultural Science,7 (5): 231-240. https://doi.org/10.5539/jas.v7n5p231

56. Lomborg B. 2001. The skeptical environmentalist. Measuring the real state of the world Cambridge, UK. https://doi.org/10.1017/CBO9781139626378

57. Mahajan S., Tuteja N. 2005. Cold, salinity and drought stresses: an overview. Archives of Biochemistry and Bionhysics. 444 (2): 139-158. https://doi.org/10.1016/j.abb.2005.10.018

58. Manivannan P., Jaleel C. A., Sankar B., Kishorekumar A., Somasundaram R., Lakshmanan G. A., Panneerselvam R. 2007. Growth, biochemical modifications and proline metabolism in Helianthus annuus L. as induced by drought stress. Colloids and Surface B: Biointerfaces, 59 (2): 141149. https://doi.org/10.1016/j.colsurfb.2007.05.002

59. Mantovani A., Iglesias R. R. 2010. The effect of water stress on seed germination of three terrestrial bromeliads from restinga. Rrazilian . Iournal of Rotany, 33 (1): 201-205. https://doi.org/10.1590/S0100-84042010000100017

60. Mohammadian R., Moghaddam M., Rahimian H., Sadeghian S. Y. 2005. Effect of early season drought stress on growth characteristics of sugar beet genotypes. Turkish Journal of Botany, 29 (5): 357-368.

61. Munné-Bosch S., Alegre L. 2004. Die and let live: leaf senescence contributes to plant survival under drought stress. Functional Plant Biology, 31 (3): 203-216. https://doi.org/10.1071/FP03236

62. Nerd A., Nobel P. S. 1991. Etfects of drought on water relations and nonstructural carbohydrates in cladodes of Onuntia ficus-indica. Physiologia Plantarum, 81 (4): 495-500. https://doi.org/10.1111/j.1399-3054.1991.tb05090.x

63. Niu J. H., Anjum S. A., Wang R., Li J. H., Liu M. R., Song J. X., Zohaib A., Lv J., Wang S. G., Zong X. F. 2016. Exogenous application of brassinolide can alter morphological and physiological traits of Leymus chinensis (Trin.) Tzvelev under room and high temperatures. Chilean Journal of Agricultural Research, 76 (1): 27-33. https://doi.org/10.4067/S0718-58392016000100004 
64. Nonami H. 1998. Plant water relations and control of cell elongation at low water potentials. Journal of Plant Research, 111 (3): 373-382. https://doi.org/10.1007/BF02507801

65. Okcu G., Kaya M. D., Atak M. 2005. Effects of salt and drought stresses on germination and seedling growth of pea (Pisum sativum L.). Turkish Journal of Agriculture and Forestry, 29 (4): 237-242.

66. Pandey V., Shukla A. 2015. Acclimation and tolerance strategies of rice (Orvza sativa L.) under drought stress. Rice Science, 22: 1-7. https://doi.org/10.1016/j.rsci.2015.04.001

67. Pelleschi S., Rocher J. P., Prioul J. L. 1997. Effect of water restriction on carbohydrate metabolism and photosynthesis in mature maize leaves. Plant. Cell and Environment, 20 (4): 493-503. https://doi.org/10.1046/j.1365-3040.1997.d01-89.x

68. Penalba O. C., Rivera J. A. 2013. Future changes in drough characteristics over Southern South America projected by a CMIP5 multi-model ensemble. American Geophysical Union, Spring Meeting Abstracts, 05. https://doi.org/10.4236/ajcc.2013.23017

69. Pervez M. A., Ayub C. M., Khan H. A., Shahid M. A Ashraf I. 2009. Effect of drought stress on growth, yield and seed quality of tomato (Lycopersicon esculentum L.). Pakistan Journal of Agricultural Science, 46: 174-178.

70. Petropoulos S. A., Daferera D., Polissiou M. G., Passam H. C. 2008. The effect of water deficit stress on the growth yield and composition of essential oils of parsley. Scientia Horticulturae. 115 (4): 393-397. https://doi.org/10.1016/j.scienta.2007.10.008

71. Pettigrew W. T. 2004. Physiological consequences of moisture deficit stress in cotton. Crop Science. 44 (4): 1265-1272. https://doi.org/10.2135/cropsci2004.1265

72. Population Reference Bureau. 2008. World population data sheet. Washington, DC.

73. Prasad P. V. V., Staggenborg S. A., Ristic Z. 2008. Impacts of drought and/or heat stress on physiological, developmental, growth, and yield processes of crop plants. Response of crops to limited water: understanding and modeling water stress effects on plant growth processes p. 301-355. <https://dl.sciencesocieties.org/publications/ books/abstracts/advancesinagric/responseofcrops/301>

74. Priestley D. A. 1986. Seed ageing: implications for seed storage and persistence in the soil. Ithaca, USA, $304 \mathrm{p}$.

75. Randall H. C., Sinclair T. R. 1988. Sensitivity of soybean leaf development to water deficit. Plant, Cell and Environment, 11 (9): 835-839. https://doi.org/10.1111/j.1365-3040.1988 tb01909.x

76. Rang Z. W., Jagadish S. V. K., Zhou Q. M., Craufurd P. Q., Heuer S. 2011. Effect of high temperature and water stress on pollen germination and spikelet fertility in rice. Environmental and Experimental Botany, 70 (1): 58-65. https://doi.org/10.1016/j.envexpbot.2010.08.009

77. Reddy A. R., Chaitanya K. V., Vivekanandan M. 2004 Drought induced responses of photosynthesis and antioxidan metabolism in higher plants. Journal of Plant Physiology, 161 (11): 1189-1202. https://doi.org/10.1016/j.jplph.2004.01.013

78. Reddy T. Y., Reddy V. R., Anbumozhi V. 2003. Physiological responses of groundnut (Arachis hypogea L.) to drough stress and its amelioration: a critical review. Plant Growth Regulation, 41 (1): 75-88. https://doi.org/10.1023/A:1027353430164

79. Richards R. A., Rebetzke G. J., Condon A. G., Van Herwaarden A. F. 2002. Breeding opportunities for increasing the efficiency of water use and crop yield in temperate cereals. Crop Science. 42 (1): 111-121. https://doi.org/10.2135/cropsci2002.1110

80. Robertson M. J., Carberry P. S., Huth N. I., Turpin J. E., Probert M. E., Poulton P. L., Bell M., Wright G. C., Yeates S. J., Brinsmead R. B. 2002. Simulation of growth and development of diverse legume species in APSIM. Australian Journal of Agricultural Research, 53 (4): 429-446. https://doi.org/10.1071/AR01106

81. Roitsch T., Ehneß3 R. 2000. Regulation of source/sink relations by cytokinins. Plant Growth Regulation. 32 (2) 359-367. https://doi.org/10.1023/A:1010781500705

82. Rucker K. S., Kevin C. K., Holbrook C. C., Hook J. E. 1995 Identification of peanut genotypes with improved drought avoidance traits. Peanut Science. 22 (1): 14-18. https://doi.org/10.3146/pnut.22.1.0003
83. Saba J., Moghaddam M., Ghassemi K., Nishabouri M. R. 2001. Genetic properties of drought resistance indices. Journal of Agricultural Science and Technology, 3: 43-49.

84. Saglam A., Kadioglu A., Demiralay M., Terzi R. 2014. Leaf rolling reduces photosynthetic loss in maize under severe drought. Acta Botanica Croatica. 73 (2): 315-323. https://doi.org/10.2478/botcro-2014-0012

85. Sain H. S., Westgate M. E. 2000. Reproductive development in grain crons during drought. Advances in Agronomy. 68: 59-96. https://doi.org/10.1016/S0065-2113(08)60843-3

86. Samarah N. H. 2005. Etfects of drought stress on growth and yield of barley. Agronomy for Sustainahle Develonment, 25 (1): 145-149. https://doi.org/10.1051/agro:2004064

87. Samarah N.,Alqudah A. 2011. Etfects of late-terminal drought stress on seed germination and vigor of barley (Hordeum vulgare L.). Archives of Agronomy and Soil Science, 57 (1): 27-32. https://doi.org/10.1080/03650340903191663

88. Sandquist D. R., Ehleringer J. R. 2003. Population- and family-level variation of brittlebush (Encelia farinosa, Asteraceae) pubescence: its relation to drought and implications for selection in variable environments. American Journal of Botany, 90 (10): 1481-1486. https://doi.org/10.3732/ajb.90.10.1481

89. Sankar B., Jaleel C. A., Manivannan P., Kishorekumar A., Somasundaram R., Panneerselvam R. 2008. Relative efficacy of water use in five varieties of Abelmoschus esculentus (L.) Moench. under water-limited conditions. Colloids and Surfaces R: Bininterfaces. 62 (1): 125-129 https://doi.org/10.1016/j.colsurfb́.2007.09.025

90. Saranga Y., Jiang C. X., Wright R. J., Yakir D., Paterson A. H. 2002. Genetic dissection of cotton physiological responses to arid conditions and their interrelationships with productivity. Plant, Cell and Environment, 27 (3): 47-58.

91. Schuppler U., He P. H., John P. C. L., Munns R. 1998. Effects of water stress on cell division and cell-division-cycle-2-like cell-cycle kinase activity in wheat leaves. Plant Physiology, 117: 667-678. https://doi.org/10.1104/pp.117.2.667

92. Schussler J. R., Westgate M. E. 1995. Assimilate flux determines kernel set at low water potential in maize. Crop Science. 35 (4): 1074-1080. https://doi.org/10.2135/cropsci1995.0011183X003500040026x

93. Shao H. B., Chu L. Y., Jaleel C. A., Manivannan P., Panneerselvam R., Shao M. A. 2009. Understanding water deficit stress-induced changes in the basic metabolism of higher plants-biotechnologically and sustainably improving agriculture and the ecoenvironment in arid regions of the globe. Critical Review in Biotechnology, 29 (2): 131-151. https://doi.org/10.1080/07388550902869792

94. Siemens J.A.,Zwiazek J. J. 2003. Etfect of water deficit stress and recovery on the rootwater relations of trembling aspen (Populus tremuloides) seedlings. Plant Science. 165 (1): 113-120. https://doi.org/10.1016/S0168-9452(03)00149-3

95. Simonneau I., Habıb K., Goutouly J. P., Buguet J. G. 1993. Diurnal changes in stem diameter depend upon variation in water content: Direct evidence from peach trees. Journal of Experimental Botany, 44 (3): 615-621. https://doi.org/10.1093/jxb/44.3.615

96. Singh T., Singh H., Malik D. S. 1986. Effect of water stress at three stages of growth on water use and water use efficiency of dwarf wheat. Indian Journal of Plant Physiology, 29: $248-255$.

97. Specht J. E., Chase K., Macrander M., Graef G. L., Chung J., Markwell J. P., Germann M., Orf J. H., Lark K. G. 2001. Sovhean resnonse to water. Cron Science 41 (2): 493-509. https://doi.org/10.2135/cropsci2001.412493x

98. Subbarao G. V., Johansen C., Slinkard A. E., Rao R. C. N., Saxena N. P., Chauhan Y. S. 1995. Strategies and scope for improving drought resistance in grain legumes. Critical Review in Plant Science. 14 (6): 469-523. https://doi.org/10.1080/07352689509701933

99. Supit 1., der (Groot E. V. (eds.). 2003. Updated system description of the WOFOST crop growth simulation model as implemented in the Crop Growth Monitoring System applied by the European Commission $<\mathrm{http}: / / \mathrm{ww} w$.supit.net/ $>$.

100. Tahir M. H. N., Mehid S. S. 2001. Evaluation of open pollinated sunflower (Helianthus annuus L.) populations under water stress and normal conditions. International Journal of Agriculture and Biology, 3: 236-238.

101. Tahir M. H. N., Imran M., Hussain M. K. 2002. Evaluation of sunflower (Helianthus annuus L.) inbred lines for drought tolerance. International Journal of Agriculture and Biology, 3: 398-400. 
102. Taiz L., Zeiger E. 2006. Plant physiology (4 $4^{\text {th }}$ ed.). Massachusetts, USA

103. Tardieu F., Reymond M., Hamard P., Granier C., Muller B. 2000. Spatial distribution of expansion rate, cell division rate and cell size in maize leaves: a synthesis of the effects of soil water status, evaporative demand and temperature. Journal of Exnerimental Botany, 51 (350): 1505-1514. https://doi.org/10.1093/jexbot/51.350.1505

104. Teruel D. A., Barbieri V., Ferraro Jr. L. A. 1997. Sugarcane leaf area index modeling under different soil water conditions. Scientia Agricola. 54: 39-44 https://doi.org/10.1590/S0103-90161997000300008

105. Torres G. A., Pflieger S., Corre-Menguy F., Mazubert C., Hartmann C., Lelandais-Brière C. 2006. Identification of novel drought-related mRNAs in common bean roots by differential disnlav RT-PCR. Plant Science. 171 (3): 300-307. https://doi.org/10.1016/j.plantsci.2006.03.008

106. Van Uosterom E. J., Borrell A. K., Deifel K. S., Hammer G. L. 2011. Does increased leaf appearance rate enhance adaptation to postanthesis drought stress in sorghum? Crop Science $51(5): 2728-2740$ https://doi.org/10.2135/cropsci2011.01.0031

107. Vasantha S., Alarmelu S., Hemaprabha G., Shanthi R. M. 2005. Evaluation of promising sugarcane genotypes for drought. Sugar Technologv. 7 (2-3): 82-83. https://doi.org/10.1007/BF02942536

108. Villalobos M. A., Bartels D., Iturringa G. 2004. Stress tolerance and glucose insensitive phenotypes in Arabidopsis overexpressing the CpMYB10 transcription factor gene. Plant Physiology. 135 (1): 309-324 https://doi.org/10.1104/pp.103.034199

109. Vyas S. P., Garg B. K., Kathju S. Lahiri A. N. 2001. Influence of potassium on water relations, photosynthesis, nitrogen metabolism and yield of clusterbean under soil moisture stress. Indian Journal of Plant Physiology, 6: 30-37.

110. Wang R., Anjum S. A., Niu J., Liu M., Li J., Zohaib A., Song J., Lv J., Wang S., Zong X. 2016. Exogenous application of brassinolide ameliorate chilling stress in Leymus chinensis (Trin.) Tzvel. by modulating morphological, physiological and biochemical traits. Bangladesh Journal of Botany, 45 (1): $143-150$

111. Weber C. R., Shibles R. M., Byth D. E. 1996. Effect of plant population and row spacing on soybean development and nroduction. A gronomy .Journal 58 (1): 99-102 https://doi.org/10.2134/agronj1966.000́21962005800010034x
112. Webber H. A., Madramootoo C. A., Bourgault M., Horst M. G., Stulina G., Smith D. L. 2006. Water use efficiency of common bean and green gram grown using alternate furrow and deficit irrigation. Agricultural Water Management. 86 (3): 259-268

https://doi.org/10.1016/j.agwat.2006.05.012

113. Winter S. R., Ohlrogge A. J. 1993. Leaf angle, leaf area and corn vield A Aronomy Iournal 65 (3) 395-397. https://doi.org/10.2134̌/agronj1973.00021962006500030013x

114. Wu Q. S., Xia R. X., Zou Y. N. 2008. Improved soil structure and citrus growth after inoculation with three arbuscular mycorrhizal fungi under drought stress. European Journal of Soil Biologv. 44 (1): 122-128. https://doi.org/10.1016/j.ejsobi.2007.10.001

115. Xu Y., Burgess P., Zhang X., Huang B. 2016. Enhancing cytokinin synthesis by overexpressing ipt alleviated drought inhibition of root growth through activating ROS-scavenging systems in Agrostis stolonifera. Journal of Experimental Botanv. 67 (6): 1979-1992 https://doi.org/10.1093/jxb/erw019

116. Yatapanage K. G., So H. B. 2001. The relationship between leaf water potential and stem diameter in sorghum. Agronomy Journal, 93 (6): 1341-1343. https://doi.org/10.2134/agronj2001.1341

117. Yin C., Wang X., Duan B., Luo J., Li C. 2005. Early growth, dry matter allocation and water use efficiency of two Sympatric populus species as affected by water stress. Fnvironmental and Fxnerimental Botany. 53 (3): 315-322. https://doi.org/10.1016/j.envexpbot.2004.04.007

118.Zeid I. M., Shedeed Z. A. 2006. Response of alfalfa to putrescine treatment under drought stress. Biologia Plantarum. 50 (4): 635-640. https://doi.org/10.1007/s10535-006-0099-9

119. Zinselmeier C'. Westgate M. E., Schussler J. R., Jones R. J. 1995. Low water potential disrupts carbohydrate metabolism in maize (Zea mavs L.) ovaries. Plant Physiology, 107 (2): 385-391. https://doi.org/10.1104/pp.107.2.385

120.Zinselmeier C., Habben J. E., Westgate M. E., Boyer J. S. 2000. Carbohydrate metabolism in setting and aborting maize ovaries. Westgate M. E., Boote K. J. (eds.). Physiology and modeling kernel set in maize. CSSA Special Publication No. 29. Madison, USA, p. 1-13.

121.Zlatev Z., Lidon F. C. 2012. An overview on drought induced changes in plant growth, water relations and photosynthesis. Emirates Journal of Food and Agriculture, 24 (1): 57-72. https://doi.org/10.9755/ejfa.v24i1.10599

ISSN 1392-3196 / e-ISSN 2335-8947

Zemdirbyste-Agriculture, vol. 104, No. 3 (2017), p. 267-276

DOI 10.13080/z-a.2017.104.034

\title{
Žemès ūkio augalų reakcija ị sausros sukurtą stresą: apžvalga
}

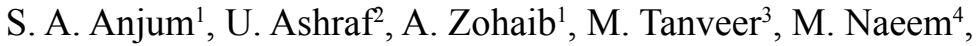 \\ I. Ali ${ }^{1}$, U. Nazir ${ }^{1}$, T. Tabassum ${ }^{1}$
}

'Pakistano žemès ūkio universitetas

${ }^{2}$ Pietų Kinijos žemès ūkio universiteto Žemès ūkio koledžas

${ }^{3}$ Tasmanijos universiteto Žemès ir maisto mokykla, Australija

${ }^{4}$ Nigde universitetas, Turkija

\section{Santrauka}

Pasaulyje nuolat didejjant gyventojų skaičiui ir siekiant užtikrinti jų aprūpinimą maistu, svarbus veiksnys yra vandens stygius, kuris turi įtakos augalų augimui ir vystymuisi - mažina jų produktyvumą. Sausros atvejų daugèja, jie skiriasi intensyvumu ir trukme. Sausros stresas turi įtakos gyvybiškai svarbiems augalų augimo ir vystymosi procesams: sudygimui, augalų aukščiui, stiebo skersmeniui, lapų skaičiui, dydžiui bei plotui, sausujų medžiagų gamybai ir pasiskirstymui, žydejjimui, vaisių mezgimui ir brandai. Susidoroti su sausros stresu augalams padeda juose vykstantys morfologiniai pakitimai, skirti sumažinti vandens nuostolius, padidinti vandens ìsisavinima ir išlaikymą audiniuose. Kad išvengtų vandens deficito sąlygų, kai kurie augalai gyvavimo ciklą užbaigia prieš prasidedant sausrai.

Sausros streso poveikio augalų morfologiniams požymiams bei pokyčiams ir jų reakcijos ị sausrą nustatymas gali padèti atrenkant ir kuriant sausrai atsparius genotipus.

Reikšminiai žodžiai: augalų reakcija, augimas ir vystymasis, fenologija, morfologija, sausra. 